\title{
Myxomycetes occurring on Cecropia adenopus (Cecropiaceae) in fragments of Atlantic Rainforest ${ }^{1}$
}

Andrea Carla Caldas Bezerra ${ }^{2,4}$, Antonia Aurelice Aurélio Costa ${ }^{3}$ and Laise de Holanda Cavalcanti ${ }^{3}$

Recebido em 29/10/2008. Aceito em 16/11/2010

\section{RESUMO}

(Myxomycetes ocorrentes em Cecropia adenopus (Cecropiaceae) em fragmentos de Floresta Atlântica). Cecropia adenopus (embaúba) é uma espécie nativa, frequente em bordas de matas e clareiras e tida como espécie pioneira em áreas recolonizadas. Apesar de ocorrer desde o México até a Argentina este substrato nunca tinha sido examinado com detalhe quanto à presença de Myxomycetes. No presente estudo, a mixobiota associada a folhas mortas de $C$. adenopus foi investigada em duas Unidades de Conservação da Floresta Atlântica, situadas no estado do Rio Grande do Norte. Cinco espécimes e um plasmódio foram obtidos diretamente no campo e 87 desenvolveram-se em 43,7\% de 200 câmaras-úmidas, montadas com lâminas foliares e pecíolos separadamente. Quinze espécies de Myxomycetes foram identificadas e ilustradas. Os dois grupos predominantes pertencem às ordens Trichiales e Physarales. Didymium columella-cavum foi encontrado pela segunda vez no Brasil e no mundo.

Palavras-chave: Cecropiaceae, Didymium, micologia, Neotrópicos, taxonomia

\begin{abstract}
(Myxomycetes occurring on Cecropia adenopus (Cecropiaceae) in fragments of Atlantic Rainforest). Cecropia adenopus (Ambay pumpwood) is a frequent native species on the edges of woods and clearings and is considered a pioneer species in re-colonized areas. Despite its distribution from Mexico to Argentina, this substrate has never been examined in detail regarding the presence of Myxomycetes. In the present study, the myxobiota associated with leaf debris of C. adenopus was investigated in two Atlantic Rainforest conservation units located in the Brazilian state of Rio Grande do Norte. Five specimens and one plasmodium were obtained directly from the field and 87 were developed in $43.7 \%$ of 200 moist-chamber cultures set up separately with blades and petioles. Fifteen species were identified and illustrated. The two predominant groups were representatives of Trichiales and Physarales. Didymium columella-cavum was recorded for the second time in Brazil and in the world.
\end{abstract}

Key words: Cecropiaceae, Didymium, mycology, Neotropics, taxonomy

\section{Introduction}

Myxomycetes are not considered phytopathogenic organisms (Agrios 1997; Nieves-Rivera 2000), but records are found in the literature regarding their occasionally harmful presence on some plant species of economic importance, such as living trunks of Acer rubrum L. (Ostrofsky \& Shigo 1981), the terminal buds of Paulinia cupana Kunth. (Pereira 1984), and stems and leaves of Solanum lycopersicum L. (Cavalcanti et al. 1985; Cabrera-de-Alvarez et al. 1993), Fragaria sp. (Metlitskii et al. 2001), Allium cepa L. (Wordell Filho 2006), Lactuca sativa L. and Petroselinum sp. (Silva \& Bezerra 2005).

A number of studies have addressed the association of myxomycetes with phanerogam families, genera and species, such as living or decomposing palm trees (Mobin \& Cavalcanti 1998/1999; 2000; Cavalcanti \& Mobin 2004; Stephenson 2003) and species of Quercus L. (Wrigley de Basanta 1998), Rizophora L. (Stephenson 1988) and Terminalia L. (Bezerra \& Cavalcanti 2007). Some of these studies have been conducted in northeastern Brazil with introduced species employed in urban tree-planting programs or native species found in different ecosystems.

The Ambay pumpwood (Cecropia adenopus Mart. ex Miq.) is a native species frequently found on the edges of woods and clearings, distributed from Mexico to Argentina and appearing in greater abundance in the Amazon region. It is considered a pioneer species in re-colonized areas. It belongs to the Cecropiaceae family, which encompasses six

\footnotetext{
1 Parte da tese de Doutorado da primeira Autora

2 Universidade Federal de Pernambuco, Centro de Ciências Biológicas, Programa de Pós-graduação em Biologia de Fungos, Departamento de Micologia, Recife, PE, Brasil

3 Universidade Federal de Pernambuco, Departamento de Botânica, Laboratório de Myxomycetes, Recife, PE, Brasil

4 Autor para correspondência: labmix@gmail.com
} 
genera and 170 species and is characterized by a hollow, curly stem that ants (myrmecophila) use for shelter; spiral phyllotaxis; peltate, palmatilobed leaves, divided radially; and long petioles with a glandular pulvinule at the base (Braga 1953).

Leaves and fruit from the Ambay pumpwood are used in folk remedies for the treatment of diabetes as well as for coughs and bronchitis. The juice extracted from the root is a powerful diuretic. Juice from the buds is often used in the treatment of diarrhea, gonorrhea and is employed by indigenous peoples on wounds produced by venomous insects. Ash from the stem is used to whiten clothes, make soap and purify sugarcane sap in the fabrication of sugar. In Brazil, the plant is normally known as "imbaúba", originating from the term "ambaíba" from the indigenous Tupi language, meaning "tree with orifice" or "tree that does not serve for construction" (Braga 1953).

In studies on the soil and shoot debris carried out on the myxobiota in Atlantic Rainforest conservation units on the coast of the state of Rio Grande do Norte (Brazil), greater attention has been given to this species due to the frequent occurrence of myxomycetes on its leaves and branches.

\section{Materials and methods}

\section{Study areas}

Sampling was carried out in two areas. The first is the Estrela Woods Natural Heritage Private Reserve (06 $22^{\prime} 10^{\prime \prime}$ - 06 $22^{\prime} 43^{\prime \prime} \mathrm{S}$ and $34^{\circ} 58^{\prime} 29^{\prime \prime}-35^{\circ} 00^{\prime} 28^{\prime \prime} \mathrm{W}, 1,833.12$ ha, 4 $\mathrm{m}$ alt.) located in the city of Baía Formosa, state of Rio Grande do Norte. The location has a rainy tropical climate, with annual precipitation of $1400 \mathrm{~mm}$ and average relative humidity of 79\% (IDEMA 2007). The physiognomy of the vegetation is typical of the Atlantic Rainforest, with large trees and contiguous crowns forming a canopy approximately 20 meters in height, with C. adenopus individuals in more illuminated areas, such as along the Gameleira trail $\left(06^{\circ} 22^{\prime} 26^{\prime \prime}-06^{\circ} 23^{\prime} 00^{\prime \prime} \mathrm{S}\right.$ and $35^{\circ} 01^{\prime} 25^{\prime \prime}$ $\left.-35^{\circ} 00^{\prime} 55^{\prime \prime} \mathrm{W}\right)$ and some points of the Pau-brasil, (06 $22^{\prime}$ $43^{\prime \prime}-06^{\circ} 23^{\prime} 19^{\prime \prime} \mathrm{S}$ and $35^{\circ} 00^{\prime} 46^{\prime \prime}-35^{\circ} 01^{\prime} 04^{\prime \prime} \mathrm{W}$ ), Pagão $\left(06^{\circ} 23^{\prime} 11^{\prime \prime}-06^{\circ} 23^{\prime} 19^{\prime \prime} \mathrm{S}\right.$ and $\left.35^{\circ} 00^{\prime} 46^{\prime \prime}-34^{\circ} 59^{\prime} 57^{\prime \prime} \mathrm{W}\right)$ and Coca-cola $\left(06^{\circ} 24^{\prime} 50^{\prime \prime}-06^{\circ} 25^{\prime} 45^{\prime \prime} \mathrm{S}\right.$ and $34^{\circ} 59^{\prime} 57^{\prime \prime}$ - $34^{\circ} 58^{\prime} 32^{\prime \prime}$ W) trails.

The other sampling area was the Natal Dunes State Park $\left(05^{\circ} 48^{\prime} \mathrm{S}-05^{\circ} 53^{\prime} \mathrm{S}\right.$ and $35^{\circ} 09^{\prime \prime} \mathrm{W}-35^{\circ} 12^{\prime \prime} \mathrm{W}, 1,172.80$ ha, 80 $120 \mathrm{~m}$ alt.), the second largest urban park in Brazil, located in the city of Natal, Rio Grande do Norte. The climate is humid, with annual precipitation of $1200 \mathrm{~mm}$. The park contains formations of dunes densely covered by sub-humid Atlantic Rainforest and a small stretch of the coastal tablelands (Freire 1990). It has large trees forming a canopy approximately 20 meters in height, with C. adenopus individuals in the lower arboreal stratum, particularly in more illuminated locations, such as the entrance of the Perobinha trail.

\section{Collection, culturing and analysis of myxobiota}

Myxomycete sporocarps were collected from branches and dead leaves (either fallen on the ground or stuck in bushes approximately $2 \mathrm{~m}$ above the ground) of C. adenopus (Figs. 1-3) individuals distributed in the interior and along the trails of the study areas between June 2004 and September 2006. Two hundred moistchamber cultures were set up, with blades and petioles placed in disposable Petri dishes $(9 \mathrm{~cm})$ lined with sterilized filter paper soaked in distilled water. The cultures were maintained at room temperature $\left(22^{\circ}\right.$ to $25^{\circ} \mathrm{C}$ ) and examined on a weekly basis for a period of three months with the aid of a stereomicroscope (Schnittler \& Stephenson 2002). Exsiccates representative of the material obtained in the field and laboratory were deposited in the UFP Herbarium of the Pernambuco Federal University. Identification of the specimens was based on morphological characters, following descriptions by Lister (1925), Martin \& Alexopoulos (1969), Farr (1976), Lado \& Pando (1997) and Mitchell (2004). Illustrations were based on the collected material. Taxonomic nomenclature and abbreviations of the names of the authors follow Hernández-Crespo \& Lado (2005).

\section{Results and discussion}

The specimens obtained belong to species distributed among the genera of five families and are characterized below:

\section{Trichiaceae}

Arcyria cinerea (Bull.) Pers., Syn. Meth. Fung. 184 (1801) $\equiv$ Trichia cinerea Bull., Herb. France pl. 477, f. 3 (1790) Fig. 4

Selected material examined: BRAZIL. Rio Grande do Norte: Natal, Natal Dunes State Park. Perobinha trail, culture 15/IV/2004, sporulation 18/V/2004, A.C.C. Bezerra et al. (UFP 40257); ibid, culture 15/IV/2004, sporulation 7/VI/2005, A.C.C. Bezerra et al. (UFP 40263); ibid, 14/ IV/2005, A.C.C. Bezerra et al. (UFP 40276); ibid, 15/ IV/2005 A.C.C. Bezerra et al. (UFP 40278).

Arcyria insignis Kalchbr. \& Cooke, in Kalchbrenner, Grevillea 10:143 (1882)

Selected material examined: BRAZIL. Rio Grande do Norte: Natal, Natal Dunes State Park. Perobinha trail, 9/ IX/2006, blade Cecropia sp., A.C.C. Bezerra et al. (UFP 40283).

Hemitrichia pardina (Minakata) Ing, Myxomycetes Britain and Ireland 132 (1999)

$\equiv$ Hemitrichia minor var. pardina Minakata, in G.Lister, Trans. Brit. Mycol. Soc. 5:82 (1915)

Fig. 5 
Table 1. Myxomycetes recorded (field/ moist-chamber culture) on dead leaves from Cecropia adenopus Mart. ex Miq. in the Natal Dunes State Park and Estrela Woods Natural Heritage Private Reserve, Rio Grande do Norte, Brazil.

\begin{tabular}{llc}
\hline Species & Petioles & Blades \\
\hline Arcyria cinerea (Bull.) Pers. & $-/ 2$ & $-/ 7$ \\
Arcyria insignis Kalchbr. \& Cooke & -- & $1 /-$ \\
Cribraria violacea Rex & $-/ 2$ & $-/ 19$ \\
Comatricha tenerrima (M. A. Curtis) G.Lister & -- & $-/ 1$ \\
Craterium leucocephalum (Pers. Ex J.F.Gmel.) Ditmar & -- & $1 /-$ \\
Diderma deplanatum Fr. & -- & $-/ 1$ \\
Diderma hemisphaericum (Bull.) Hornem & -- & $-/ 4$ \\
Didymium columella-cavum Hochg., Gottsb. \& Nann.-Bremek & $-/ 3$ & $-/ 22$ \\
Didymium squamulosum (Alb. \& Schwein.) Fr. & -- & $1 /-$ \\
Hemitrichia pardina (Minakata) Ing & -- & $-/ 21$ \\
Lycogala epidendrum (L.) Fr. & $1 /-$ \\
Perichaena chrysosperma (Curr.) Lister & -- & -- \\
Perichaena depressa Lib. & $-/ 2$ \\
Physarum melleum (Berk. \& Broome) Massee & -- & $-/ 1$ \\
Physarum stellatum (Massee) G. W. Martin & -- & $-/ 1$ \\
\hline Total & $1 / 9$ & $-/ 1$
\end{tabular}

Selected material examined: BRAZIL. Rio Grande do Norte: Baía Formosa, RPPN Estrela Woods, Gameleira trail, culture 11/VI/2004, sporulation 25/VI/2004, A.C.C. Bezerra et al. (UFP 50262); ibid, sporulation 9/VII/2004, A.C.C. Bezerra et al. (UFP 50258); ibid, sporulation 9/IX/2004, A.C.C. Bezerra et al. (UFP 50578); ibid, sporulation 1/VII/2004, A.C.C. Bezerra et al. (UFP 50182); ibid, sporulation 9/VII/2004, A.C.C. Bezerra et al. (UFP 50382); ibid, sporulation 12/VII/2004, A.C.C. Bezerra et al. (UFP 50179).

Perichaena chrysosperma (Curr.) Lister, Monogr. Mycetozoa 196 (1894)

$\equiv$ Ophiotheca chrysosperma Curr., Quart. J. Microscop. Sci.

2:241 (1854)

Fig. 6

Selected material examined: BRAZIL. Rio Grande do Norte: Baía Formosa, RPPN Estrela Woods, Gameleira trail, culture 14/VI/2004, sporulation 09/VIII/2004, A.C.C. Bezerra et al. (UFP 50296).

Perichaena depressa Lib., Pl. Crypt. Arduenna 378 (1837) Fig. 7

Selected material examined: BRAZIL. Rio Grande do Norte: Baía Formosa, RPPN Estrela Woods, Gameleira trail, culture 14/VI/2004, sporulation 25/ VI/2004, A.C.C. Bezerra et al. (UFP 50266); culture 14/VI/2004, sporulation 9/IX/2004, A.C.C. Bezerra et al. (UFP 40247).

\section{Liceaceae}

Cribraria violacea Rex, Proc. Acad. Nat. Sci. Philadelphia 43:393 (1891)

Fig. 8

Selected material examined: BRAZIL. Rio Grande do Norte: Baía Formosa, RPPN Estrela Woods, Gameleira trail, culture 14/VI/2004, sporulation 05/VII/2004, A.C.C. Bezerra et al. (UFP 50193); ibid., sporulation 08/IX/2004, A.C.C. Bezerra et al. (UFP 50378); ibid., sporulation 05/VII/2004, A.C.C. Bezerra et al. (UFP 50374). Natal, Natal Dunes State Park, sporulation 11/IX/2006, A.C.C. Bezerra et al. (UFP 50563).

Lycogala epidendrum (L.) Fr., Syst. Mycol. 3: 80 (1829)

三 Lycoperdon epidendrum L., Sp. Pl.: 1184. (1753)

Selected material examined: BRAZIL. Rio Grande do Norte: Natal, Natal Dunes State Park. Perobinha trail, 14/ IV/2005, Cecropia sp., A.C.C. Bezerra et al. (UFP 40296).

\section{Physaraceae}

Craterium leucocephalum (Pers. ex J.F.Gmel.) Ditmar, in Sturm, Deutschl. Fl. Pilze 1(1):21 (1813)

$\equiv$ Stemonitis leucocephala Pers. ex J.F.Gmel., Syst. Nat. 2:1467 (1792)

Selected material examined: BRAZIL. Rio Grande do Norte: Natal, Natal Dunes State Park. Perobinha Trail, 14/ IV/2005, A.C.C. Bezerra et al. (UFP 40288).

Physarum melleum (Berk. \& Broome) Massee, Monogr. Myxogastr. 278 (1892) 
इDidymium melleum Berk. \& Broome, J. Linn. Soc., Bot. 14:83 (1873)

Fig. 9

Selected material examined: BRAZIL. Rio Grande do Norte: Baía Formosa, RPPN Estrela Woods, Gameleira trail, culture 14/VI/2004, sporulation 21/VII/2004, A.C.C. Bezerra et al. (UFP 50178); ibid, sporulation 29/VI/2004, A.C.C. Bezerra et al. (UFP 50202).

Physarum stellatum (Massee) G. W. Martin, Mycologia 39(4):461 (1947)

$\equiv$ Lepidoderma stellatum Massee, in Cooke, Grevillea 17:60 (1889)

Selected material examined: BRAZIL. Rio Grande do Norte: Baía Formosa, RPPN Estrela Woods, Gameleira trail, culture 14/VI/2004, sporulation 9/VIII/2004, A.C.C. Bezerra et al. (UFP 50210).

\section{Didymiaceae}

Diderma hemisphaericum (Bull.) Hornem., Fl. Dan. 33:13 (1829)

$\equiv$ Reticularia hemisphaerica Bull., Herb. France pl. 446, f. 1 (1790)

Fig. 10

Selected material examined: BRAZIL. Rio Grande do Norte: Baía Formosa, RPPN Estrela Woods, Gameleira trail, culture 14/VI/2004, sporulation 09/VII/2004, A.C.C. Bezerra et al. (UFP 50371); ibid, sporulation 09/VIII/2004, A.C.C. Bezerra et al. (UFP 50790); ibid, sporulation 10/IX/2004, A.C.C. Bezerra et al. (UFP 50787); ibid, sporulation 08/IX/2004, A.C.C. Bezerra et al. (UFP 50379)

Diderma deplanatum Fr., Syst. Mycol. 3:110 (1829)

Selected material examined: BRAZIL. Rio Grande do Norte: Baía Formosa, RPPN Estrela Woods, Gameleira trail, culture 14/VII/2004, sporulation 27/VII/2004, A.C.C. Bezerra et al. (UFP 50782)

Didymium columella-cavum Hochg., Gottsb. \& Nann.Bremek., Proc. Kon. Ned. Akad. Wetensch., C. 92(1):73 (1989)

Fig. 11

Selected material examined: BRAZIL. Rio Grande do Norte: Baía Formosa, RPPN Estrela Woods, Gameleira trail, culture 11/VI/2004, sporulation 9/VII/2004, A.C.C. Bezerra et al. (UFP 50368); ibid, sporulation 15/VII/2004, A.C.C. Bezerra et al. (UFP 50177); ibid, sporulation 10/ IX/2004, A.C.C. Bezerra et al. (UFP 50376); ibid, sporulation 9/VIII/2004, A.C.C. Bezerra et al. (UFP 50783); ibid, sporulation 9/VIII/2004, A.C.C. Bezerra et al. (UFP 50210); ibid, sporulation 3/VIII/2004, A.C.C. Bezerra et al. (UFP 50375). Natal, Natal Dunes State Park, Gameleira Trail, sporulation 11/IX/2006, A.C.C. Bezerra et al. (UFP 40896).
Didymium squamulosum (Alb. \& Schwein.) Fr., Symb. Gasteromyc. 19 (1818)

三Diderma squamulosum Alb. \& Schwein., Consp. Fung. Lusat. 88 (1805)

Fig. 12

Selected material examined: BRAZIL. Rio Grande do Norte: Natal, Natal Dunes State Park. Perobinha trail, 14/IV/2005, Cecropia sp., A.C.C. Bezerra et al. (UFP 40290).

\section{Stemonitaceae}

Comatricha tenerrima (M.A.Curtis) G.Lister, Guide Brit. Mycetozoa, ed. 439 (1919)

$\equiv$ Stemonitis tenerrima M.A.Curtis, Amer. J. Sci. Arts 6:352 (1848)

Fig. 13

Selected material examined: BRAZIL. Rio Grande do Norte: Baía Formosa, RPPN Estrela Woods, Gameleira trail, culture 14/VI/2004, sporulation 23/VII/2004, A.C.C. Bezerra et al. (UFP 50197).

On eight expeditions to the study areas between 2004 and 2006, five specimens and one plasmodium were obtained directly from the field on C. adenopus leaves that had fallen to the ground and 87 specimens were developed in $43.7 \%$ of the moist-chamber cultures set up separately with blades and petioles. On these collections, 10 genera and 15 species were represented, most belonging to Physarales (47\%) and Trichiales (33\%). In the cultures set up with leaf blades, $H$. pardina, $C$. violacea and D. columella-cavum predominated (Figs. 5; $8 ; 11$ ), representing $80.5 \%$ of the specimens. More than half $(60 \%)$ of the species were recorded only once either in the field or in the laboratory. Most of the species recorded in the present study are commonly cited as foliicolous, except Arcyria cinerea (Fig. 4), which does not have a substrate preference.

The specimens form a set of species that are associated with $C$. adenopus for the first time. However, some species of the myxobiota studied can be considered rare or at least uncommon in microenvironments. Didymium columella-cavum, for example, is recorded for the second time for both Brazil and the world and was previously known only from a description made by Hochgesand et al. (1989) at two sites in São Paulo state on palm leaves and mosses. Nonetheless, this was one of the species with the greatest number of records in the present study (over 20 specimens). The relative diversity of myxomycetes fructifying on C. adenopus leaves may be attributed to the long, hollow petiole and palmed venation blade as well as lobed margins that, upon drying, roll up and form a natural moist chamber, similar to that observed by Stephenson (2003) studying 

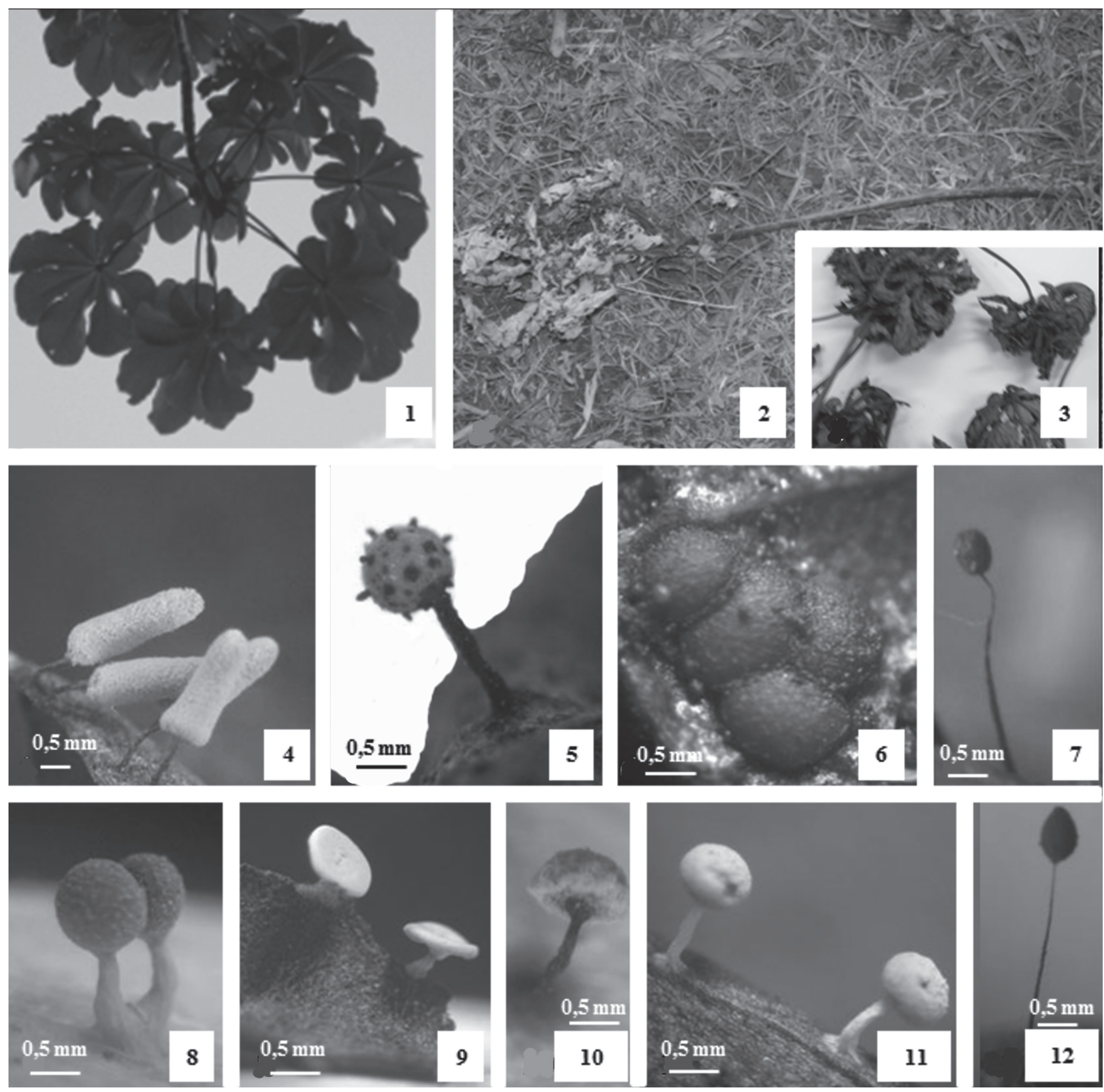

Figures 1-12. Cecropia adenopus Mart. ex Miq. 1. View of upper stratum of Ambay pumpwood individual. 2-3. Blade and leaf petiole fallen on the ground. 4. Arcyria cinerea (Bull.) Pers. 5. Hemitrichia pardina (Minakata) Ing. 6. Perichaena depressa Lib. 7. Cribraria violacea Rex. 8. Physarum melleum (Berk. \& Broome) Massee. 9. Diderma hemisphaericum (Bull.) Hornem. 10. Didymium columella-cavum Hochg., Gottsb. \& Nann.-Bremek. 11. Didymium squamulosum (Alb. \& Schwein.) Fr. 12. Comatricha tenerrima (M.A.Curtis) G.Lister.

myxomycetes associated with the palm tree Rhopalostylis in New Zealand. In collections carried out at the Tapacurá Ecological Station in Pernambuco state (Brazil) in 2007, (I. N. Ferreira, personal communication), five species of myxomycetes were obtained from a single dead unidentified Cecropia individual. However, despite possessing such characteristics and being distributed from Mexico to Argentina, particularly in the Amazon region, no studies were found in the literature reporting that $C$. adenopus or any other species of the genus has served as substrate for the development of myxomycetes.

\section{Acknowledgments}

The authors are grateful to the staff of the Myxomycetes Laboratory (LABMIX) for help in both the field and laboratory, especially Alissandra Nunes, David Lemos, Fátima Bezerra, Glauciane Damasceno, Inaldo Ferreira, Juciara Tenório, Leandro Agra, Marcio Rufino and Wendell Medrado; to the administration of the Estrela Woods Natural Heritage Private Reserve and Natal Dunes State Park for support during the collection period; to the Conselho Nacional de Desenvolvimento Científico 
e Tecnológico (CNPq) for financial support; and to the Departmento de Botânica of the Universidade Federal de Pernambuco for the physical support.

\section{References}

Agrios, G.N. 1997. Plant Pathology. Lonfon, Academic Press.

Bezerra A.C.C. \& Cavalcanti L.H. 2007. Mixobiota corticicola de Terminalia catappa L. (Combretaceae). Sitientibus Serie Ciências Biológicas 7: 154-160.

Braga, R. 1953. Plantas do Nordeste, especialmente do Ceará. Fortaleza, Centro de Divulgação Universitária - Estudos e Ensaios Biblioteca de Divulgação e Cultura Publicação.

Cabrera-de-Alvarez, M.G.; Mazzanti-de-Castanon, M.A. \& Cundom, M.A. 1993. Suffocation of tomato seedings by a true slime mold (Myxomycetes), in the northeast of Argentina. Fitopatologia 28:10-15.

Cavalcanti, L.H \& Mobin, M. 2004. Myxomycetes associated with palm trees at the Sete Cidades National Park, Piauí State, Brazil. Systematics and Geography of Plants 74: 109-127.

Cavalcanti, L.H.; Correia, A.M.S. \& Porto, K.C. 1985. O Herbário de Myxomycetes (Gymnomycota) da UFPE. Pp 189-199. In: Anais do $33^{\circ}$ Congresso Nacional de Botânica Brasília, DF. 1982. São Paulo, Sociedade Botânica do Brasil.

Farr, M.L. 1976. Myxomycetes. Flora Neotropica. Mon. 16. New York, The New York Botanical Garden.

Freire, S.M.B. 1990. Levantamento florístico do Parque Estadual das Dunas de Natal. Acta Botanica Brasilica 4: 41-59.

Hernandez-Crespo, J.C. \& Lado, L. 2005. An on-line nomenclatural information system of Eumycetozoa. http://www.nomen. eumycetozoa.com (Acesso em 14/07/07).

Hoechgesand, E.; Gottsberger, G. \& Nannenga-Bremekamp, N.E. 1989. A new species and a new variety of Didymium from São Paulo State, Brazil. Proceedings. Koninklijke Nederlandse Akademie van Wetenschappen.Ser.C, Biological and Medical Sciences 92: 73-79.

IDEMA. 2007 (Instituto de Desenvolvimento Econômico e Meio Ambiente do Rio Grande do Norte). Rio Grande do Norte. Informativo Municipal: Baia Formosa. Natal, IDEMA.
Lado C. \& Pando F. 1997. Flora Micológica Ibérica. Myxomycetes I.V.2. Berlin, Cramer.

Lister A. 1925. A monograph of the Mycetozoa. $3^{\text {a }}$. ed., Londres, British Museum of Natural History.

Martin, G.W. \& Alexopoulos, C.J. 1969. The Myxomycetes. Iowa, University of Iowa Press.

Metlitskii, O.Z.; Undritsova, I.A.; Lakhov, V.S. \& Sviridov, V.D. 2001. Slime mold of Strawberry. All-Russian Institute of Breeding and Technology of Horticulture and Nurseries 11: 35-36.

Mitchell, D. 2004. A key to corticolous Myxomycota. Systematics and Geography of Plants 74: 261-285.

Mobin, M. \& Cavalcanti, L.H. 1998/1999. Myxomycetes sobre buriti (Mauritia vinifera L. f; Arecaceae). Revista da Universidade do Amazonas, Série Ciências Biológicas 2/3: 43-51.

Mobin, M. \& Cavalcanti, L.H. 2000. Myxomycetes em Carnaúba (Copernicea prunifera, Arecaceae). Acta Botanica Brasilica 14: 71-75.

Nieves-Rivera A.M. 2000. Are myxomycetes phytopathogens? Inoculum 51: $2-4$.

Ostrofsky, A. \& Shigo, A.L. 1981. A myxomycete isolated from discolored wood of living red maple. Mycologia 73: 997-1000.

Pereira, L.V. 1984. Nova doença fúngica do guaranazeiro causada por um mixomiceto. Fitopatologia Brasileira 9: 161-163.

Schnittler, M. \& Stephenson, S.L. 2002. Inflorescences of Neotropical herbs as a newly discovered microhabitat for myxomycetes. Mycologia 94: 6-20.

Silva, G.S. \& Bezerra, J.L. 2005. Ocorrência de Fuligo septica em alface e coentro de caboclo. Fitopatologia brasileira 30: 439-439.

Stephenson, S.L. 1988. Distribution and ecology of Myxomycetes in the temperate forests I: patterns of occurrence in the upland forests of Southwestern Virginia. Canadian Journal of Botany 66: 2187-2207.

Stephenson, S.L. 2003. Myxomycetes associated with decaying fronds of nikau palm (Rhopalostylis sapida) in New Zealand. Journal of Botany 41: 311-317.

Wordell Filho, J.A.; Rowe, E.; Gonçalves, P.A.; Debarba, J.F.; Boff, P. \& Thomazelli, L.F. 2006. Manejo fitossanitario na cultura da cebola. Florianópolis, Epagri.

Wrigley de Basanta, D. 1998. Myxomycetes de la corteza de Quercus ilex. Anales del Jardin Botánico de Madrid 56(1): 3-14. 